\title{
In Vitro a-amylase Inhibitory Potential and in Vivo Hypoglycemic Effect of Organic Extracts of Phrynium Imbricatum Roxb. Leaves
}

Md. Razibul Habib ${ }^{1}$, Mohammad Shah Hafez Kabir ${ }^{2}$, Md. Mominur Rahman ${ }^{2}$, Mohammed Munawar Hossain ${ }^{2}$, Hazrat Ali ${ }^{2}$, Jakir Ahmed Chowdhury $^{3}$, Md. Atiar Rahman ${ }^{4^{*}}$

${ }^{1}$ Superintendent of Drugs, Directorate General of Drug Administration, Bangladesh;

2 Department of Pharmacy, International Islamic University Chittagong, Chittagong-4203, Bangladesh;

${ }^{3}$ Department of Pharmaceutical Technology, Faculty of Pharmacy, University of Dhaka, Dhaka-1000, Bangladesh;

${ }^{4}$ Department of Biochemistry and Molecular Biology, University of Chittagong, Chittagong-4331, Bangladesh.

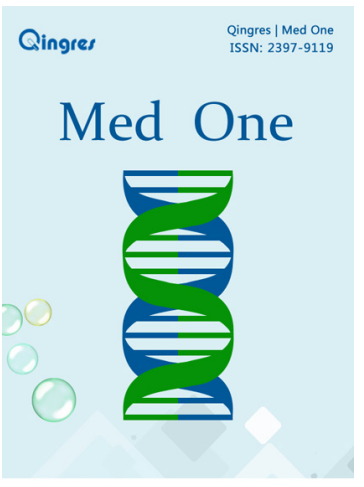

http://mo.qingres.com

\section{GOPEN ACCESS}

DOI: $10.20900 / \mathrm{mo} .20170026$

Received: October 18, 2017

Accepted: November 14, 2017

Published: November 29, 2017

Copyright: ๑2017 Cain et al. This is an open access article distributed under the terms of the Creative Commons Attribution License, which permits unrestricted use, distribution, and reproduction in any medium, provided the original author and source are credited.
Corresponding Author: *Dr. Md. Atiar Rahman, Associate Professor, Department of Biochemistry and Molecular Biology, Faculty of Biological Sciences, University of Chittagong, Chittagong-4331, Bangladesh, Tel: 88-031-2606001-14 (Extn. 4334); Fax: 88-031726310; Cell: +88-01711709084, E-mail: atiar@cu.ac.bd or atiarh@ yahoo.com.

\section{ABSTRACT}

Background: Diabetes has become one of the major burdens for developing country people mainly due to excessive cost and adverse effects of synthetic drugs. Plant-derived drugs in Bangladesh is currently being paid an emerging attention because of low cost and diverse floral distribution. This research investigated the in vitro $\alpha$-amylase inhibitory and hypoglycemic activity of organic etracts of Phrynium imbricatum in normal and glucose induced hyperglycemic mice.

Methods: Extracts were undertaken to measure in vitro a-amylase activity using starch-iodine method while the hypoglycemic effect was studied in glucose induced hyperglycemic mice.

Results: All the extracts of P. imbricatum (EEPI) showed considerable a-amylase inhibitory activity and chloroform extract (CHPI) showed 
the highest activity among them as compared to Acarbose the reference antidiabetic drug. The extracts at $400 \mathrm{mg} / \mathrm{kg}$ and $800 \mathrm{mg} / \mathrm{kg}$ b.w. significantly $(p<0.05)$ reduced fasting glucose level in normal mice as compared to standard drug glibenclamide $(5 \mathrm{mg} / \mathrm{kg}$ ) but $\mathrm{CHPI}$ at 800 $\mathrm{mg} / \mathrm{kg}$ showed the highest hypoglycemic effect decreasing $23.78 \%$ of blood glucose level after $2 \mathrm{~h}$ of administration in normal mice, while glibenclamide decreased $49.30 \%$. In oral glucose tolerance test, at $400 \mathrm{mg} / \mathrm{kg}$ and $800 \mathrm{mg} / \mathrm{kg}$ of extracts significantly reduced blood glucose level $(p<0.05)$ at $30 \mathrm{~min}$. Area under the curve (AUC) of the extracts were at the range of $12.895-14.258 \mathrm{hr} . \mathrm{mmol} / \mathrm{L}$., and 14.573 $\mathrm{hr} . \mathrm{mmol} / \mathrm{L}$ and $9.835 \mathrm{hr} . \mathrm{mmol} / \mathrm{L}$ for control and glibenclamide respectively.

Conclusion: The results demonstrate that Phrynium imbricatum may be a very remarkable source for the development of new oral antihyperglycemic agent.

Keywords: Phrynium imbricatum; Hypoglycemic activity; AUC; Ethanol extract

\section{INTRODUCTION}

Diabetes is a metabolic disorder usually caused due to either complete or partial dysfunction of insulin secretion with or without varying degrees of insulin resistance ${ }^{[1]}$. Diabetes involves high blood glucose levels regardless of the type of diabetes. Pancreatic a-amylase constitutes a family of endoamylases which catalyze the cleavages of a-D-(1-4) glycosidic bonds in diabetes incidences ${ }^{[2]}$. Therefore, inhibition of a-amylase is considered to be one of the major therapeutic strategies for the treatment of diabetes through the retardation of digestion of dietary carbohydrates which are absorbed as monosachharides from intestinal lumen and transported into blood circulation ${ }^{[3]}$. However, the major drawback of these synthetic inhibitors are their non-specificity in targeting glycosidases eventually produce serious side effects ${ }^{[4]}$. Thus plant derived drugs are important area of investigation with great potential for discovery of new antidiabetic drugs. Several different medicinal plants and plant-derived drugs have been using for treating diabetes in traditional medicine system as well as in ethnomedicinal practices ${ }^{[6]}$. This is due to the lesser side effects, cost effective and availability of plant based drugs compared to the synthetic hypoglycemic agents ${ }^{[7]}$ Additionally, different plants have been reported to show a-amylase inhibitory activity and they may be relevant to the treatment of diabetes ${ }^{[5]}$.

Phrynium imbricatum (Family: Marantaceae) is a herbaceous plant distributed in the forests of Chittagong, Chittagong Hill Tracts, Cox's Bazar and Sylhet. A paste prepared from leaves of P. imbricatum (locally called Khedom gach) is applied to wound and fractures (Chakma) ${ }^{[8]}$. Leaves of P. imbricatum is as also used as anthelmintic, antiarthritic and membrane stabilizing ${ }^{[8,9]}$. This research is designed to investigate the $\alpha$-amylase inhibitory and hypoglycemic effect of organic extracts (ethanol, chloroform and petroleum ether) of $\mathrm{P}$. imbricatum leaves in normal and glucose induced hyperglycemic mice.

\section{MATERIALS AND METHODS}

\subsection{Chemicals and Reagents}

All the chemicals and reagents used in this research were analytical grade. Ethanol, chloroform and petroleum ether were purchased from Merck, Germany. A-amylase was procured from SigmaAldrich (Sigma-Aldrich Co., USA). Starch, iodine was purchased from Fluka (Fluka chemie $\mathrm{GmbH}, \mathrm{CH}-$ 9471 Buchs). Shimadzu Biospec 1601 UV-visible spectrophotometer (Shimadzu, Japan) was used to measure the absorbance. Rapid ViewTM (Blood glucose monitoring system, Model: BIO-M1, BIOUSA Inc, California, USA) with strips were purchased from local suppliers. Acarbose was procured from the local scientific market, Chowkbazar, Chittagong. Glibenclamide was kindly donated by Square Pharmaceutical Ltd., Bangladesh.

\subsection{Plant sample collection and identification}

Leaves of P. imbricatum (accession No. 1315 CTGUH) were collected from Alu Tila, Khagrachari, Chittagong, Bangladesh in the month of September 2014 at the late phase of its flowering. It was authenticated by Dr. Shaikh Bokhtear Uddin, Professor and taxonomist, Department of Botany, University of Chittagong, Chittagong-4331, Bangladesh.

\subsection{Extraction of plant material}

Leaves were cleaned, dried for a period of $10 \mathrm{~d}$ under shade and powdered with a mechanical grinder, passing through sieve \#40 to store in a tight container. Resulting powder $(850 \mathrm{~g})$ was successively soaked in ethanol, chloroform and petroleum ether for $7 \mathrm{~d}$ each of $2 \mathrm{~d}$ approximately with occasional stirring and filtered through a cotton 
plug followed by Whatman filter paper number 1 . The extract was then concentrated by using a rotary evaporator at reduced temperature and pressure ${ }^{[10]}$. A total of $55 \mathrm{~g}$ of ethanol extract (EEPI), $8 \mathrm{~g}$ of chloroform extract (CHPI) and $14 \mathrm{~g}$ of petroleum ether (PEFPI) was measured to preserve at $4^{\circ} \mathrm{C}$ for future endeavor.

\subsection{Experimental animals and experimental set-up}

Swiss albino mice of both sexes, weighing about 28$35 \mathrm{~g}$, were collected from the animal house of the Department of Pharmacy, Jahangir Nagar University, Bangladesh. The animals were acclimatized to laboratory condition for $7 \mathrm{~d}$ prior to experimentation. They were individually housed in polycarbonated cage at standard laboratory temperature $23 \pm 2{ }^{\circ} \mathrm{C}$ and relative humidity $55-60 \%$ ensuring standard pellete diet and drinking water ad libitum maintaining a regular $12 \mathrm{hr}$ day-night cycle. All the experiments were conducted in an isolated and noiseless condition. The study protocol was approved by the P\&D Committee, Department of Pharmacy, International Islamic University Chittagong, Bangladesh. All animal experiments were carried out according to the guidelines of Institutional Animals Ethics Committee and study protocols were approved by the Department of Pharmacy, International Islamic University Chittagong Medical Ethics, Biosafety.

\subsection{In vitro $\alpha$-amylase inhibitory activity}

This experiemnt was conducted by a modified starch-iodine protocol described by Hossain et al. ${ }^{[11]}$. Briefly, $1 \mathrm{~mL}$ of plant extract or standard of different concentrations $(2,1,0.5 \mathrm{mg} / \mathrm{mL})$ was taken in prelabeled test tubes. The reaction mixture contained $20 \mu$ of $\alpha$-amylase solution $(10 \mathrm{mg} / \mathrm{mL})$, phosphate buffer $(0.02 \mathrm{M}, \mathrm{pH} 7.0)$ with $0.006 \mathrm{M} \mathrm{NaCl}(0.4 \mathrm{~mL})$ was added to each test tube and incubated for 10 $\min$ at $37{ }^{\circ} \mathrm{C}$. After the incubation, $200 \mu$ l of $1 \%$ starch solution was added to each test tube and the mixture was re-incubated for $1 \mathrm{~h}$ at $37^{\circ} \mathrm{C}$. Then $200 \mu$ of $1 \%$ iodine solution was added followed by adding $10 \mathrm{~mL}$ distilled water to each test tube. The absorbance of the mixture was taken at 565 $\mathrm{nm}$. Sample, substrate and $\alpha$-amylase blank were undertaken under the same conditions. Each experiment was done in triplicate. IC50 value was calculated by using regression analysis:

$$
\% \alpha \text {-amylase inhibition }=\left[1-\frac{(\mathrm{SA}-\mathrm{SBB}-\mathrm{SMB})}{\mathrm{AAB}}\right] \times 100
$$

SA = Sample absorbance, SMB = Sample blank, $\mathrm{SBB}=$ Substrate blank, $\mathrm{AAB}=\alpha$-amylase blank

\subsection{Acute toxicity test and dose selection}

Twenty Swiss albino female mice were used for acute toxicity test. Mice were divided into four groups of five animals for each group. Different doses (1000 mg/kg, $2000 \mathrm{mg} / \mathrm{kg}, 3000 \mathrm{mg} / \mathrm{kg}$ and 4000 $\mathrm{mg} / \mathrm{kg}$ ) of EEPI, CHPI and PEPI were administered by stomach tube. Organoleptic changes or any other abnormality of the the animals were recorded for next $24 \mathrm{~h}$. Cage side was observed once daily to note the changes of skin and fur, eyes and mucous membrane, respiratory and circulatory rate, autonomic and central nervous system (CNS). The effective therapeutic dose was taken based on median lethal dose $(\text { LD50 }>2.0 \mathrm{~g} / \mathrm{kg})^{[12]}$.

\subsection{Experimental protocol for in vivo hypoglycemic activity}

\subsubsection{Hypoglycemic effect in normal mice}

Mice were randomLy divided into eight groups (Group I-Group VIII) each containing five animals. Group I was treated as a control, Group II was treated with glibenclamide (5 mg/kg body weight), Group III-VIII were treated with EEPI and CHPI and PEPI at the doses of $400 \mathrm{mg} / \mathrm{kg}$ and $800 \mathrm{mg} / \mathrm{kg}$ body weight respectively. Before the treatment, animals were fasted overnight with free access to water and fasting blood glucose levels were measured (Rapid ViewTM blood glucose monitoring system, Model: BIO-M1, BIOUSA Inc, California, USA) ${ }^{[13]}$. Blood glucose levels were reestimated after $2 \mathrm{~h}$ of administration of drug and extract solutions. Percent decrease of blood glucose level after $2 \mathrm{~h}$ was calculated using the following equation:

$$
\% \text { decrease }=\frac{\left(G L_{\text {before }}-G L_{\text {after }}\right)}{G L_{\text {before }}} \times 100
$$

$\mathrm{GL}_{\text {before }}=$ Blood Glucose level before drug or extract administration, $\mathrm{GL}_{\text {after }}=$ Blood Glucose level after drug or extract administration.

\subsubsection{Hypoglycemic effect of glucose induced hyperglycemic mice (OGTT)}

Oral glucose tolerance test (OGTT) was performed according to the standard method with minor modification $^{[14]}$. Group I was treated as a normal control group, Group II treated with glibenclamide (5 
$\mathrm{mg} / \mathrm{kg}$ body weight), Group III-VIII were treated with EEPI, CHPI and PEPI at the doses of $400 \mathrm{mg} / \mathrm{kg}$ and $800 \mathrm{mg} / \mathrm{kg}$ body weight respectively. Sugar solution (1 $\mathrm{g} / \mathrm{kg}$ body weight) was orally administrated to each animal and the blood glucose levels were measured at 0 (just before sugar ingestion), 30, 60,90 , and 120 min after the administration. Areas under the curves (AUC) for OGTT were calculated to evaluate glucose tolerance ${ }^{[15]}$. Percent decrease of blood glucose level after 120 min was calculated by the following equation,

$$
\% \text { decrease }=\frac{\left(G L_{0 \text { min }}-G_{120 \text { min }}\right)}{G L_{0 \text { min }}} \times 100
$$

$\mathrm{GL}_{0 \text { min }}=$ Blood Glucose level at $0 \mathrm{~min}, \mathrm{GL}_{120 \mathrm{~min}}=$ Blood Glucose level at $120 \mathrm{~min}$.

\subsection{Statistical analysis}

Data were expressed as the mean \pm SEM. The results were analyzed with the software Statistical Package for Social Science (SPSS, Version 22.0, IBM corporation, NY) using One way Aanalysis of variance (ANOVA) followed by Dunnett's and Bonferroni multiple comparisons when compared against control in OGTT. Paired t-test was performed to show significant variation between before and after blood glucose level. Student's t-test was performed between IC50 values. Regression analysis was performed to calculate IC50 values. $p<$ 0.05 was considered as statistically significant.

\section{RESULTS}

\subsection{In vitro $\alpha$-amylase inhibitory activity}

In vitro $\alpha$-amylase inhibitory action of EEPI, CHPI and PEFI were presented in Table 1. Three of the extracts were found to show very notable $\alpha$-amylase inhibition. CHPI showed the highest inhibition and it's IC50 was found to be $2.504 \pm 0.023 \mathrm{mg} /$ $\mathrm{mL}$ which is lower than others and statistically significant $(p<0.001)$ compared to that of standard antihyperglycemic agent (acarbose) of IC50 $0.912 \pm$ $0.015 \mathrm{mg} / \mathrm{mL}$. However, $\alpha$-amylase inhibitory effects were noted as a dose-dependent phenomenon like Acarbose. The strength of a-amylase inhibitory actions of the extracts were graded as CHPI > EEPI $>$ PEPI.

Table 1. IC50 values $(\mathrm{mg} / \mathrm{mL})$ for the leaf extracts of $P$. imbricatum and Acarbose in $\alpha$-amylase inhibitory assay

\begin{tabular}{lcccc}
\hline $\begin{array}{l}\text { Extract/ } \\
\text { Standard }\end{array}$ & Concentrations in $\mathrm{mg} / \mathrm{mL}$ with $(\%$ Inhibition $)$ & IC50 value $\mathrm{mg} / \mathrm{mL}$ \\
\hline Acarbose & $0.25(15.89 \pm 1.117)$ & $0.50(26.05 \pm 0.438)$ & $1.00(55.38 \pm 0.888)$ & $0.912 \pm 0.015 \mathrm{a}$ \\
EEPI & $0.5(19.24 \pm 0.754)$ & $1.00(28.15 \pm 0.684)$ & $2.00(41.78 \pm 0.826)$ & $2.536 \pm 0.019 \mathrm{~b}$ \\
CHPI & $0.5(20.31 \pm 0.465)$ & $1.00(28.15 \pm 0.578)$ & $2.00(42.56 \pm 0.652)$ & $2.504 \pm 0.023 \mathrm{~b}$ \\
PEPI & $0.5(17.46 \pm 0.546)$ & $1.00(27.61 \pm 0.846)$ & $2.00(37.26 \pm 0.568)$ & $2.945 \pm 0.031 \mathrm{c}$ \\
\hline
\end{tabular}

Values are the mean of triplicate experiments and represented as mean \pm SEM $(n=3)$. Values in the same column with different superscripts are significantly different ${ }^{a} p<0.05,{ }^{b} p<0.01,{ }^{c} p<0.001$. Student's t test was performed to analyze this data set.

\subsection{Acute toxicity study}

None of the animals were found to show behavioral, neurological or physical changes characterized by symptoms such as reduced motor activity, convulsions, restlessness, coma, diarrhea and lacrimation at the limit dose of $4000 \mathrm{mg} / \mathrm{kg}$ of EEPI, $\mathrm{CHPI}$ and PEPI during the observation period. Additionally, no mortality was observed at the test doses. Thus, the median lethal dose (LD50) of the plant extract was found to be greater than $4000 \mathrm{mg} /$ 
$\mathrm{kg}$. Therefore, the doses $400 \mathrm{mg} / \mathrm{kg}$ body weight and $800 \mathrm{mg} / \mathrm{kg}$ body weight have been selected for in vivo study (one thenth of LD50) ${ }^{[16]}$.

\subsection{Hypoglycemic effect in normal mice}

Hypoglycemic effect of the extracts is presented in Table 2. Both the doses of EEPI, CHPI and
PEPI showed a reduction of blood glucose statistically significant $(p<0.05-0.001)$ compared to glibenclamide. These results suggest the similar significance level for hypoglycemic activity of 800 $\mathrm{mg} / \mathrm{kg}$ extracts and glibenclamide. The dose of 800 $\mathrm{mg} / \mathrm{kg}$ of CHPI decreased blood glucose level 23.78 $\%$ which was higher than other treatments, except standard glibenclamide.

Table 2. Effect of P. imbricatum extracts on fasting blood glucose level (mmol/L) in normal mice

\begin{tabular}{llccc}
\hline Group & Dose (oral) & Before administration & After administration & \% decrease \\
\hline Control & $10 \mathrm{~mL} / \mathrm{kg}$ & $5.49 \pm 0.134$ & $6.29 \pm 0.181 \mathrm{a}$ & - \\
Glibenclamide & $5 \mathrm{mg} / \mathrm{kg}$ & $5.74 \pm 0.167$ & $2.91 \pm 0.164 \mathrm{~b}$ & $49.30 \pm 0.75$ \\
EEPI & $400 \mathrm{mg} / \mathrm{kg}$ & $5.28 \pm 0.191$ & $4.59 \pm 0.209 \mathrm{c}$ & $13.07 \pm 1.16$ \\
EEPI & $800 \mathrm{mg} / \mathrm{kg}$ & $5.22 \pm 0.123$ & $4.02 \pm 0.193 \mathrm{~d}$ & $22.99 \pm 0.88$ \\
CHPI & $400 \mathrm{mg} / \mathrm{kg}$ & $5.56 \pm 0.215$ & $4.80 \pm 0.224 \mathrm{c}$ & $13.48 \pm 0.74$ \\
CHPI & $800 \mathrm{mg} / \mathrm{kg}$ & $5.30 \pm 0.187$ & $4.04 \pm 0.313 \mathrm{~d}$ & $23.78 \pm 0.69$ \\
PEPI & $400 \mathrm{mg} / \mathrm{kg}$ & $5.44 \pm 0.202$ & $4.80 \pm 0.175 \mathrm{c}$ & $11.72 \pm 0.91$ \\
PEPI & $800 \mathrm{mg} / \mathrm{kg}$ & $5.46 \pm 0.197$ & $4.38 \pm 0.226 \mathrm{~d}$ & $19.84 \pm 0.63$ \\
\hline
\end{tabular}

Values are presented in mean \pm SEM $(n=6)$. EEPI $=$ Ethanol extract of $P$. imbricatum, CHPI = Chloroform extract and PEPI = Pet ether extract. A) Values in same row with different superscripts are significantly different $(p<0.05)$. Paired t-test was performed to analyze before and after relationship. B) Values with different superscripts in same column are significantly different from control after the administration of standard and different doses of the extracts. One-way ANOVA followed by Dunnett's multiple comparison was performed to analyze this comparison.

\subsection{Eeffect on glucose load in induced hyperglycemic mice (OGTT)}

Table 3 describes the oral glucose tolerce data for experimental animals. Induction of hyperglycemia resulted an increased blood glucose level at 30 min of all the treatments and continued till $60 \mathrm{~min}$.
Promising reduction of glucose load was recorded for $800 \mathrm{mg} / \mathrm{kg}$ of EEPI, CHPI and PEPI at $120 \mathrm{~min}$ and their glucose tolerance levels were significant comaperd to $(p<0.05)$ standard glibenclamide (5 $\mathrm{mg} / \mathrm{kg}$ ). These findings suggest that $800 \mathrm{mg} / \mathrm{kg}$ dose is more potent than $400 \mathrm{mg} / \mathrm{kg}$ dose. All the data and results of AUC of OGTT are presented in Fig. 1.

Table 3. Effect of P. imbricatum leaf extracts on glucose induced hyperglycemia ( $\mathrm{mmol} / \mathrm{L}$ ) in normal mice.

\begin{tabular}{|c|c|c|c|c|c|c|c|}
\hline Group & Dose & $0 \mathrm{~min}$ & $30 \mathrm{~min}$ & $60 \mathrm{~min}$ & $90 \mathrm{~min}$ & $120 \mathrm{~min}$ & $\begin{array}{c}\% \\
\text { decrease }\end{array}$ \\
\hline Control & 10 mL/kg & $6.52 \pm 0.35$ & $7.46 \pm 0.37 a$ & $7.80 \pm 0.49 a$ & $7.28 \pm 0.39 a$ & $6.69 \pm 0.21 a$ & - \\
\hline Glibenclamide & 5 mg/kg & $6.46 \pm 0.24$ & $5.6 \pm 0.18 b$ & $4.7 \pm 0.19 b$ & $4.24 \pm 0.17 b$ & $3.8 \pm 0.15 b$ & 41.18 \\
\hline
\end{tabular}




\begin{tabular}{|c|c|c|c|c|c|c|c|}
\hline EEPI & $400 \mathrm{mg} / \mathrm{kg}$ & $5.58 \pm 0.30$ & $8.42 \pm 0.2 c$ & $6.7 \pm 0.14 c$ & $5.82 \pm 0.24 c$ & $5.28 \pm 0.3 c$ & 5.38 \\
\hline EEPI & $800 \mathrm{mg} / \mathrm{kg}$ & $6.12 \pm 0.22$ & $9.74 \pm 0.33 d$ & $6.38 \pm 0.38 c$ & $5.96 \pm 0.33 c$ & $5.44 \pm 0.27 c$ & 11.11 \\
\hline $\mathrm{CHPI}$ & $400 \mathrm{mg} / \mathrm{kg}$ & $5.46 \pm 0.19$ & $8.24 \pm 0.12 c$ & $6.58 \pm 0.07 c$ & $5.68 \pm 0.14 c$ & $5.12 \pm 0.18 c$ & 6.23 \\
\hline $\mathrm{CHPI}$ & $800 \mathrm{mg} / \mathrm{kg}$ & $5.98 \pm 0.17$ & $9.48 \pm 0.36 d$ & $6.4 \pm 0.23 c$ & $5.82 \pm 0.27 c$ & $5.3 \pm 0.22 c$ & 11.37 \\
\hline PEPI & $400 \mathrm{mg} / \mathrm{kg}$ & $5.66 \pm 0.26$ & $8.46 \pm 0.15 c$ & $6.76 \pm 0.11 c$ & $5.92 \pm 0.20 c$ & $5.38 \pm 0.26 c$ & 4.95 \\
\hline PEPI & $800 \mathrm{mg} / \mathrm{kg}$ & $6.4 \pm 0.27$ & $9.55 \pm 0.24 d$ & $6.74 \pm 0.32 c$ & $6.12 \pm 0.27 d$ & $5.81 \pm 0.25 d$ & 9.22 \\
\hline
\end{tabular}

Values are presented in mean \pm SEM $(n=6)$. EEPI=Ethanol extract of $P$. imbricatum, CHPI = Chloroform extract and $\mathrm{PEPI}=$ Pet ether extract. A) Values with different superscripts in same column are significantly different from control at each specific hour after the administration of standard and different doses of the extracts $(p>0.05)$. One-way ANOVA followed by Dunnett's multiple comparison was performed to analyze this comparison. B) Values with different superscripts are significantly different from each other in the same column among standard and different doses of the extracts. Bonferroni multiple comparison was performed.

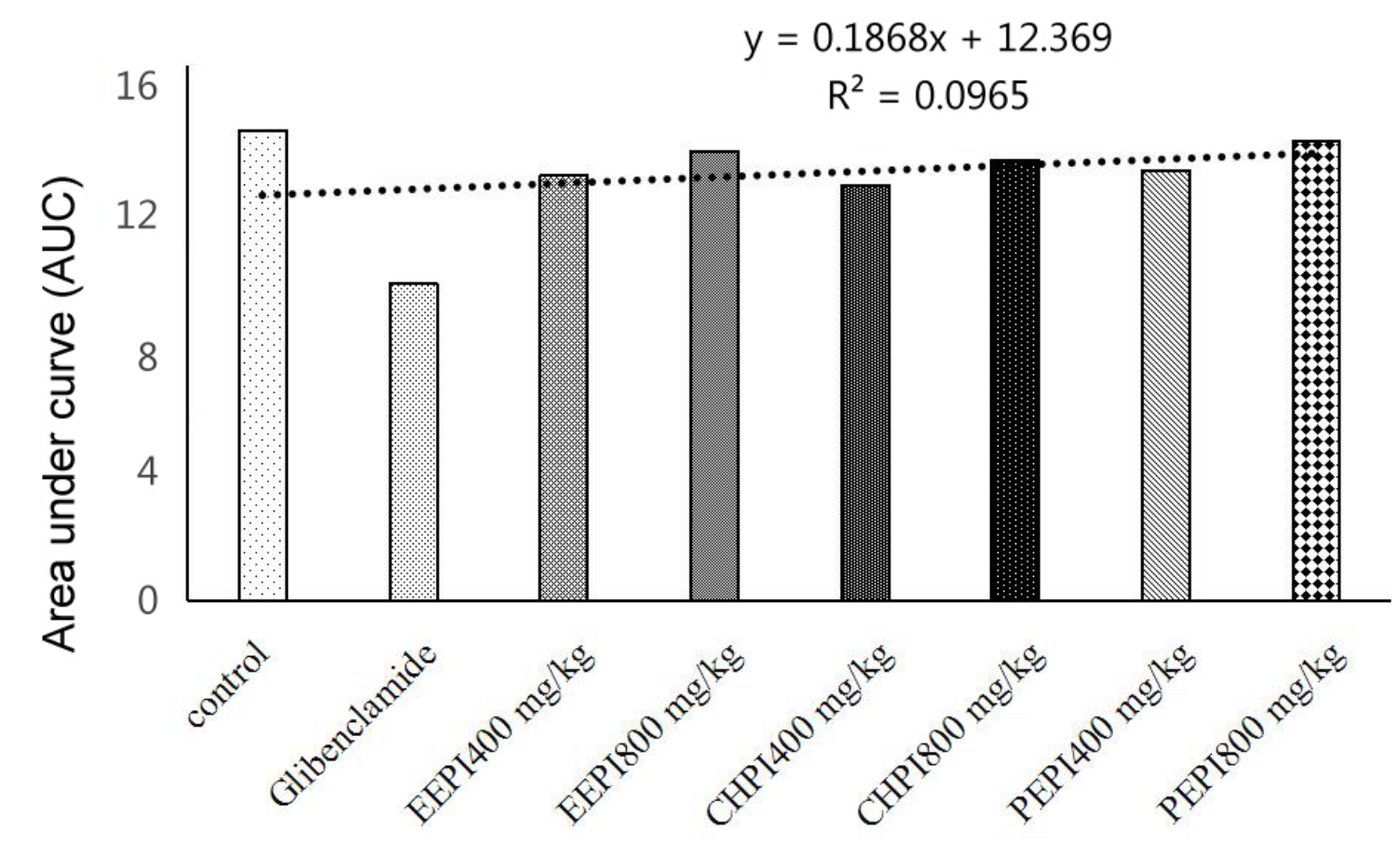

Fig. 1 Effect in context of area under curve (AUC) of P. imbricatum leaf extracts on glucose induced hyperglycemia $(\mathrm{mmol} / \mathrm{L})$ in normal mice. 


\section{DISCUSSION}

This research was undertaken to evaluate the hypoglycemic effect organic leaves extract of $P$. imbricatum, in normal, glucose-loaded hyperglycemic rats. No lethality or no toxicity was found with the selected doses until the end of intervention period. The results of the study have shown that the organic extract of leaves at dose $800 \mathrm{mg} / \mathrm{kg}$ has a marked hypoglycemic activity by improvement of the glucose tolerance test in normoglycemic rats. There are multiple options of diabetes while plant based treatment is one of the most popular options nowa-days. This study started with the aim of inhibiting a-amylase, carbohydrate-digesting enzyme, which delays carbohydrate digestion eventually blunting the post-prandial increase of plasma glucose ${ }^{[17-21]}$. The mechanism involves the inhibition of the conversion of disaccharide to monosaccharide to decrease the rate of entry of glucose into the systemic circulation [22-24].

The oral glucose tolerance test is usually assigned for screening the changes of postprandial glcemia as well as to measure body's ability to use glucose. The extracts P. imbricatum leaves showed marked ability to manage elevated glucose level in normal mice compared to the standard drug glibenclamide. The best glucose tolerance ability of $\mathrm{CHPI}$ could be linked with its highest $\alpha$-amylase inhibitory activity which ensures the higher possibility of best hypoglycemic effect.

Comparison of area under the curve of the treatment groups showed a positive and incremental AUC $\left(r^{2}=0.0965\right)$ for some of the groups indicating the strong correlation of treatment with glycemic rise. The mechanism by which this leaf extracts exerted this outcome may be due to its action on carbohydrate binding regions of $\alpha$-amylase enzymes that catalyze the hydrolysis of the internal $\alpha-1$, 4 glucosidic linkages in starch and other related polysaccharides have also been targeted for the suppression of postprandial hyperglycemia ${ }^{[25,26]}$. Therefore, this and previous study support the claim that natural inhibitors from dietary plants have $\alpha$-amylase inhibitory activity and could be used as successful therapy for the management of postprandial hyperglycemia with least side effects.

\section{CONCLUSIONS}

We can conclude that $P$. imbricatum may have both $\alpha$-amylase inhibition activity and hypoglycemic effect. It is a rational deduction that this plant may recover the metabolism of glucose and increase insulin secretion by stimulating beta cells. It is possible to propose that the bioactive compounds present in the leaf extracts may be responsible for versatile effects. However, further co-ordinate and wellstructured studies would be required to isolate the bioactive compounds and determine their underlying molecular mechanism of action on diabetes-induced mice model. These findings suggest that the plant may be a potential source for the development of new oral hypoglycemic agent.

\section{ABBREVIATIONS}

DM: Diabetes Mellitus;

EEPI: Ethanol extract of P. imbricatum;

CHPI: Chloroform extract;

PEPI: Pet ether extract;

OGTT: Oral glucose tolerance test;

h: Hour;

min: Minutes;

sec: Second;

kg: Kilogram;

g: Gram;

Mg: Microgram;

L: liter;

$\mathrm{mL}$ : Millilitre;

$\mu \mathrm{L}$ : Micro liter;

$\mu \mathrm{g} / \mathrm{mL}$ : Microgram per Milliliter;

$\mathrm{mg} / \mathrm{kg}$ : Milligram per kilogram;

mmol: millimole;

IC50: half maximal inhibitory concentration;

LD50: Median lethal dose;

et al.: et alliori (and others);

SEM: Standard error for mean.

\section{AUTHOR'S CONTRIBUTIONS}

This work was carried out in collaboration with authors. Authors MSHK and MMH collected the plant leaves and prepared the extracts. MAR and MSHK carried out the study design, data interpretation, manuscript preparation and statistical analysis. MSHK, MMH, SKS, MSR and MRH participated in experiments, data collection, and literature 
search. MAR supervised the study design and data interpretation. Author JAC and HA helped in data interpretation and manuscript preparation. All authors read and approved the final version of the manuscript.

\section{ACKNOWLEDGMENT}

The authors are grateful to the authority of International Islamic University Chittagong, Bangladesh, for providing the facilities to conduct

\section{REFERENCES}

1. Jarald E, Balakrishnan SJ, Jain DC. Diabetes and herbal medicines. Iran J Pharmocol Ther. 2008; 7: 97-106.

2. Kandra L. a-Amylases of medical and industrial importance. J Mol Struct. 2003; 666-667: 487498.

3. Dewi RT, Iskandar YM, Hanafi M, Kardono LB, Angelina M, Dewijanti ID, Banjarnahor SD. Inhibitory effect of Koji Aspergillus terreus on a-glucosidase activity and postprandial hyperglycemia. Pak J Biol Sci. 2007; 10: 31313135.

4. Cheng AYY, Fantus IG. Oral antihyperglycemic therapy for type 2 diabetes Mellitus. Can Med Assoc J. 2005; 172: 213-226.

5. de Sales PM, de Souza PM, Simeoni LA, Magalhães $P O$, Silveira D. a-Amylase inhibitors: A review of raw material and isolated compounds from plant source. J Pharm Pharm Sci. 2012; 15: 141-183

6. Sudha P, Smita SZ, Shoba YB, Ameeta RK. Potent $\alpha$-amylase inhibitory activity of Indian Ayurvedic medicinal plants. BMC CAM. 2011; 11: 5

7. Patel DK, Kumar R, Laloo D, Hemalatha $S$. Diabetes mellitus: An overview on its pharmacological aspects and reported medicinal plants having antidiabetic activity. Asian Pac J Trop Biomed. 2012; 2(5): 411-420.

8. Hossain M, Kabir MS, Kibria AS, Hasnat A, Kabir $\mathrm{MI}$, Chowdhury TA. Investigation of in vitro antiarthritic and membrane stabilizing activity of ethanol extracts of three Bangladeshi plants. Pharma Innovat J; 2015; 4(1): 76-80.

9. Kabir MSH, Dinar AMM, Hossain MM, Noman this research work. The authors are also thankful to all members of GUSTO (A research group), specially to Nishan Chakrabarty (Department of Pharmacy, IIUC) and Muhammad Abdulla Al Noman (Department of Pharmacy, USTC) for their kind help in the experiment.

\section{CONFICTS OF INTEREST}

The authors declare that they have no conflicts of interest.

MAA, Zaheed F, Hossain MR, Hasnat A, Dash R, Rahman MM, Hosen MZ. Effects of ethanol extract and its different fractions of Phrynium imbricatum (Roxb) leaves on in vitro anthelmintic and their condensed tannin content. Pharm Anal Chem Open Access. 2015; 1: 1

10. Kupchan SM, Tsou G, Sigel CW. Datiscacin, a novel cytotoxic cucurbitacin 20-acetate from Datisca glomerata. J Org Chem. 1973; 38(7): 1420-1421.

11. Hossan SJ, El-Sayed M, Aoshima H. Antioxidative and anti $\alpha$-amylase activities of four wild plants consumed by nomads in Egypt. Orient Pharm Exp Med. 2009; 9(3): 217224.

12. Zaoui A, Cherrah $\mathrm{Y}$, Mahassini N, Alaoui K, Amarouch $\mathrm{H}$, Hassar M. Acute and chronic toxicity of Nigella sativa fixed oil. Phytomedicine. 2002; 9: 69-74.

13. Walum E. Acute oral toxicity. Environ Health Perspect. 1998; 106(Suppl 2): 497-503.

14. Barham D, Trinder P. An improved color reagent for the determination of blood glucose by oxidase system. Analyst. 1972; 97: 142-145.

15. Vigneaud DU, Karr WG. Carbohydrate utilization: I. rate of disappearance of d-glucose from the blood. J Biol Chem. 1925; 66: 281-300.

16. Matthews DR, Hosker JP, Rudenski AS, Naylor BA, Treacher DF, Turner RC. Homeostasis model assessment: insulin resistance and beta-cell function from fasting plasma glucose and insulin concentrations in man. Diabetologia. 1985; 28: 412-419.

17. Jo SH, Cho CY, Lee JY, Ha KY, Kwon YI, Apostolidis $\mathrm{E}$. In vitro and in vivo reduction of 
post-prandial blood glucose levels by ethyl alcohol and water Zingiber mioga extracts through the inhibition of carbohydrate hydrolyzing enzymes. BMC Complent Altern Med. 2016; 16: 111.

18. Matsui T, Ogunwande IA, Abesundara KJ, Matsumoto K. Anti-hyperglycemic potential of natural products. Mini Rev Med Chem. 2006; 6(3): 349-356.

19. Matsuda H, Morikawa T, Yoshikawa M. Antidiabetogenic constituents from several natural medicines. Pure Appl Chem. 2002; 74(7): 1301-1308.

20. Ogunwande IA, Matsui T, Fujise T, Matsumoto K. a-Glucosidase inhibitory profile of Nigerian medicinal plants in immobilized assay system. Food Sci Technol Res. 2007; 13(2): 169-172.

21. Andrade-Cetto A., Becerra-Jiménez J., Cárdenas-Vázquez R. Alfa-glucosidaseinhibiting activity of some Mexican plants used in the treatment of type 2 diabetes. J Ethnopharmacol. 2008; 116(1): 27-32.

22. Ye F, Shen Z, Xie M. A-glucosidase inhibition from a Chinese medical herb (Ramulus mori) in normal and diabetic rats and mice. Phytomedicine. 2002; 9(2): 161-166.

23. Mohamed EA, Ahmad M, Ang LF, Asmawi MZ, Yam MF. Evaluation of a-Glucosidase Inhibitory Effect of $50 \%$ Ethanolic Standardized Extract of Orthosiphon stamineus Benth in Normal and Streptozotocin-Induced Diabetic Rats. Evid Based Complement Alternat Med. 2015; 2015: 754931.

24. Apostolidis E, Kwon Y-I, Shetty K. Inhibitory potential of herb, fruit, and fungal-enriched cheese against key enzymes linked to type 2 diabetes and hypertension. Innov Food Sci Emerg Technol. 2007; 8(1): 46-54.

25. Hanson RL, Nelson RG, McCance DR, Beart JA, Charles MA, Pettitt DJ, Knowler WC. Comparison of screening tests for non-insulindependent diabetes mellitus. Arch Intern Med. 1993; 153: 2133-2140.

26. Fonseca V, Inzucchi MSE, Ferrannini E, Redefining the Diagnosis of Diabetes Using Glycated Hemoglobin. Diabetes Care. 2009; 32(7): 1344-1345. 